Article

\title{
Philanthropy and Human Flourishing in Patristic Theology
}

\section{Helen Rhee}

History of Christianity, Westmont College, 955 La Paz Road, Santa Barbara, CA 93108, USA; rhee@westmont.edu

Received: 23 June 2018; Accepted: 29 October 2018; Published: 15 November 2018

check for updates

\begin{abstract}
This article grounds early Christian theologies and practices of philanthropy in their varied complexities in a larger patristic vision of human flourishing. For patristic authors (second to fifth centuries), human flourishing is grounded in God's creative intent for material creation, including nature and material goods, that are to be shared for common use and common good, and also to be a means of distributive justice. Based on God's own philanthropia ("love of humanity", compassionate generosity), when Christians practice it mainly through almsgiving to the poor and sharing, they mirror the original image (eikon) of God, undo their crime of inhumanity, retain a Christian identity and virtue, and thus restore a semblance of God's creative intent for the common good. This fundamental social virtue, philanthropia, is, in fact, an attendant virtue of salvation (the goal of creation, including humanity), in reversing the effects of the fall and restoring human flourishing. I then examine patristic authors' presentations of how wealth presents Christians in concrete situations with a unique challenge and opportunity to demonstrate their spiritual state and persevere in their salvation by eliminating vices (e.g., greed) and cultivating virtues (e.g., detachment), and thereby to affirm and confirm their Christian identities. Finally, I explore the institutional aspect of philanthropy in the (post-) Constantinian era as the Christian church took on the task of caring for the poor of the whole Roman society as a result.
\end{abstract}

Keywords: philanthropia; human flourishing; philanthropy; wealth; almsgiving; detachment; greed/avarice; hospitals

\section{Introduction}

Material things exist to assist with life; surely they were not given as a provision for wickedness? They constitute a ransom for the soul; surely they were not provided as an occasion for your own destruction?

-Basil the Great, Hom. 7.7

Human flourishing always encompasses both external and internal dimensions of life; the "external" or communal dimension includes material circumstances, social systems and relations, and physical conditions of a person whereas the "internal" or individual dimension involves the very soul and spiritual and affective aspect of a person. In patristic theology, these two dimensions of human flourishing naturally work in relation to each other and are closely interwoven as Basil's opening words show. This article examines an indispensable role and comprehensive impact of theologies and practices of philanthropy in their varied complexities in a larger patristic vision of human flourishing. For patristic authors (second to fifth centuries), human flourishing is grounded in God's creative intent for material creation, including nature and material goods, that are to be shared for common use and common good, and also to be a means of distributive justice. Based on God's own philanthropia ("love of humanity", compassionate generosity), when Christians practice philanthropy mainly through almsgiving to the poor and sharing, they mirror the original image (eikon) of God, 
undo their crime of inhumanity, retain a Christian identity and virtue, and thus restore a semblance of God's creative intent for the common good. This fundamental social virtue, philanthropia, is, in fact, an attendant virtue of salvation (the goal of creation, including humanity), in reversing the effects of the fall and restoring human flourishing. I will then examine patristic authors' presentations of how wealth presents Christians in concrete situations with a unique challenge and opportunity to demonstrate their spiritual state and persevere in their salvation by eliminating vices (e.g., greed) and cultivating virtues (e.g., detachment and generosity), and thereby to affirm and confirm their Christian identities. Finally, I will explore the institutional aspect of philanthropy in the (post-) Constantinian era as the Christian church took on the task of caring for the poor of the whole Roman society as a result.

\section{Results}

\subsection{Creation, Philanthropia, and Human Flourishing ${ }^{1}$}

The early church fathers clearly lay out God's intent of the creation of the material world and God's absolute ownership of the created world. While patristic authors in general hardly denied legitimacy of private property, ${ }^{2}$ they considered it as a share of the common creation that was intended for the common use and the common good (koinōfelēs); all material goods (which were never to substitute spiritual goods and virtues but were vehicles of spiritual goods) are God's gracious gifts intended for sustenance and sufficiency of all humans through common access. ${ }^{3}$ Therefore, human possession of earthly wealth is good when it fulfills God's creative purpose-sufficient provision of one's needs and the needs of others for common enjoyment and flourishing. On the one hand, this basic affirmation and attitude validates the material dimension of complex human needs and legitimates appropriateness and necessity of sufficiency and common enjoyment of earthly goods for life on earth (in subordination to heavenly goods-the ultimate priority and object of love). On the other hand, it also means that the needs of others also matter in human stewardship of God-given possessions and that they should influence people's decisions about their money or property. Human ownership is always conditional in light of God's absolute ownership and creative purpose (the common good). Beyond sufficiency and common enjoyment, people ("the rich") do not have a "natural right" to accumulation of wealth, attachment to wealth, and conspicuous display of wealth, all of which are symptoms of love of wealth, because people's possessions, even as fruit of their labor, are always contingent upon human social responsibility and creaturely witness to God's ownership. Furthermore, while all wealth ultimately comes from God (for most patristic theologians), it does accompany a real and powerful temptation, danger, and deceitfulness, which are actualized in those manifestations of avarice, in the repeated warnings of the church fathers.

Clement of Alexandria was the first theologian to probe God's creative intent for material goods and theology of wealth in dialogue with Greco-Roman classical tradition. God created all things for all people; for the rich to hoard and appropriate an undue share of goods and wealth beyond what is necessary and useful, is to oppose God's very creative purpose and intent for human flourishing (Paed. 2.13.120). ${ }^{4}$ Thus, avarice and luxury cause and result in the eternally damning consequences in

1 Parts of this section on Clement of Alexandria and Lactantius are revised from Rhee (2012, pp. 170-71, 135-37).

2 A major exception is an anonymous Pelagian treatise, De divitiis ("On Riches"), which was deemed heretical. A few patristic authors such as Ambrose and John Chrysostom, while acknowledging private ownership in practice, wrestle with affirming its legitimacy (e.g., Ambrose, De Nab. 1, 2; De off. 1.28.132; Chrysostom, Hom. 1 Tim. 12.4). See the discussion on John Chrysostom on pp. 5-6.

3 This was passed on as the common good, "universal destination of goods", and "social mortgage" in Catholic Social Teachings; cf. Pope Pius XI, Quadragesimo Anno (1931), p. 84; Pope John XXIII, Mater et Magistra (1961), pp. 78-80; John XXIII, Pacem in Terris (1963), pp. 53-59; John Paul II, Centesimus Annus (1991), p. 30; Catholic Catechism \#2420ff.; Hicks (2010, p. 74).

4 Clement's understanding of natural or proper wealth based on its "use" and "necessity" in contrast to unnatural or irrational wealth, i.e., superfluity with illiberality (non-use) or luxury (misuse), is very much like Middle Platonist Plutarch's line of argument in his On Love of Wealth, who in turn follows that of classical authors. 
both the vertical relationship with God and horizontal relationship with humanity. Clement's doctrine of creation informs his argument for common use of property as a principle against avarice and luxury:

God created our race for sharing (koinonia) beginning by giving out what belonged to God, God's own Word (logos), making it common (koinos) to all humans, and creating all things for all. Therefore all things are common (koina) ... To say therefore, 'I have more than I need, why not enjoy?' is neither human nor proper to sharing (koinōnikon) ... For I know quite well that God has given us the power to use; but only to the limit of that which is necessary; and that God also willed that the use be in common. (Paed. 2.13.120; trans. Gonzalez)

The purpose of God's creation of humanity is for sharing, which is demonstrated first by God's sharing of the divine logos. What makes us human is our sharing in this logos. Hence, for anyone not to share with others what is meant to be shared, i.e., "all things" created, rebels against the very koinonia, which is a foundation and principle of our creation and flourishing. ${ }^{5}$ Although we are created for a higher order than mere material things of the world that are transient, God has made them for our use, and all humans are given access to these material things as means of necessary sustenance (Strom. 4.13). Thus, our "right" of property is limited by the legitimate use made of it-i.e., meeting our needs and the needs of fellow humans-"avoiding all excess and inordinate affection" (Strom. 4.13; cf. Quis div. 14, 26). ${ }^{6}$

Basil of Caesarea echoes Clement in delineating social purpose and function of the created world, particularly material goods, for the common benefit of all (koinoffelēs). ${ }^{7}$ All animals use in common the plants of the earth; herds of horses feed upon the same plain, and all creatures allow one another to satisfy their needs for food as the earth welcomes all to its abundance. Then how much more should humans join in this common sharing and use of God's bounty for mutual flourishing (Hom. 8.8; Hom. 6.5)? In his Homily on Psalm 14 (LXX), Basil links this social purpose and shared nature of the creation directly to God's creative intent for human nature:

"Give to the man who begs from you; do not turn your back on the man who borrows from you" (Matt 5.42). This saying of our Lord invites us to share (koinōkos) and love one another, in natural kinship (tei fusei oikeion). Human, indeed, is a civic and social animal (sunagelastikon ho anthrōpos). Now, in social relations and in common life (koinē politeia), a certain disposition to share one's goods is necessary in order to assist the needy. (para. 1) ${ }^{8}$

Intrinsic to creation and human nature is sharing, mutual love, and responsibility toward one another (cf. Hom. 6.5). ${ }^{9}$ God's design for humanity and human flourishing is clear: made as social beings (koinonikoi anthrōpoi), people are to live in proper relation to their neighbor and the world and therefore to God by fulfilling their social obligations.

Clement and Basil represent a common patristic understanding of creation as the paradigm of human flourishing. A classical parallel, which was in fact incorporated by patristic writers, was the concept of a Golden Age, in which there was natural fecundity, social innocence, and natural justice, and against which the present state of society and its vice was measured. Indeed, between Clement and Basil, Lactantius in his Divine Institutes reflected both traditions and synthesized primal justice, equality, and acts of humanitas as indispensable aspects of original human flourishing. ${ }^{10}$ He sets up a

5 Cf. See Lactantius's vision and Gregory of Nazianzus below.

6 Cf. Peter of Alexandria, On Riches 14: "He [God] did not give it [wealth] to you [a rich man] for you to revel in it with worthless men and frivolous people or mocking theater performers. Nor did he give it to you so you could hide it in the earth, nor did he give it to you so you could spend it on large houses beyond the standard of life of the men of old. But he has given it to you so you (could) eat and give to the poor with it and those who are in need".

7 Hom. 6.5; also Cyprian, Eleem. 25.

8 Basil's text used in this paper is my translation unless it is noted otherwise.

9 See also John Chrysostom, Hom. 1 Tim. 12.4: "common sharing is more convenient and more agreeable to our nature".

10 On Lactantius's vision of social transformation (through Constantine), see (Hughson 2011, pp. 185-205, especially 193-98). 
primeval social paradigm through a Golden Age to which he returns for envisioning a Christian social ideal in the present. He regards the Golden Age (with the rule of Saturn) as the time of worship of one true God, where people lived in harmony and contentment and shared the God-given land in which "all need was met in common" as intended by God (Inst. 5.5.5—quoting Virgil). As he sees primal monotheism as an essential feature of the Golden Age, only true religion (i.e., Christianity) can offer justice (iustitia) and its derivative, fairness or equality (aequitas) as its natural consequence. Civil justice (i.e., Greco-Roman pagan justice), derived from relative and utilitarian civil laws, is not real justice, due to its polytheism (paganism) and their consequent social inequality. In contrast, natural justice, which derives from God's single, uniform rule, is true justice because of divine reward and retribution at the Judgment (Inst. 5.18). Only natural justice breeds true equality: "the whole force of justice lies in the fact that everyone who comes into this human estate on equal terms is made equal by it" (5.14.20). Everyone has equal standing before God because God created all human beings as imago Dei and because God judges inner disposition and virtues not outer status markers or distinctions. Here, Lactantius understands private property and economic distinctions compatible with Christian justice and aequitas.

In this paradigm, the key to achieving and acting out Christian justice and aequitas in the present (in his society) is service to fellow humans. Following true religion, Christians are called to true compassion, i.e., following the divine law of mutual love and care (i.e., works of charity) grounded in the bond of humanity (6.10.1-8). Lactantius believes that the common bond of humanity should generate a sense of solidarity and compassion (misericordia) for one another and is a basis of aequitas (6.10.8-9). Since it is unnatural to hurt someone by virtue of the same humanity, as Cicero says, it is only natural to do good to others $(6.11 .2,6)$. In doing good to others, we should not make any distinction among the worthy and unworthy (6.11.6-7). Here, Lactantius debunks a deeply seated Greco-Roman custom of reciprocity and patronage; he essentially links their reciprocity to utilitas, the basis of the unjust civil law. People think whatever they give to those in need is a waste and act on their self-interest and immediate advantage so as to target their charity and largesse only to "suitable people", i.e., those who can repay and return the favor (6.11.6-12). In contrast, Christian generosity and charity should be directed to "the unsuitable" as far as possible, "because a deed done with justice, piety and humanity is a deed you do without expectation of return" (6.11.13). If true virtue pursues duty and not reward, as Cicero himself maintained, then measure justice, "which is mother and head of the virtues", admonishes Lactantius, "at its own price and not by its advantage to you; offer it most of all to someone from whom you can expect nothing" (6.11.16). Well before the passionate arguments of the Cappadocian Fathers and John Chrysostom in the East, and Ambrose in the West, Lactantius champions humanitas of "the needy and the useless" (6.11.28):

Give to the blind, the sick, the lame and the destitute: if you don't, they die. Men may have no use for them, but God has: he keeps them alive, gives them breath and honours them with light. Cherish them as much as you can, and sustain their souls with humanity so that they do not die. Anyone who can help a dying man but doesn't is his murderer. $(6.11 .18-19)^{11}$

God's universal law prescribes that we provide for others through humanitas what we provide for our own family through affection; that is the whole point of justice $(6.12 .21,31)$. Thus, aequitas in the present is something that is irrespective of social and economic distinctions but demands that the works of justice be directed to the poor and the desperate ("the needy and the useless") —entirely irrespective of their worthiness and reciprocity.

Gregory of Nazianzus also affirms God's justice (isotes), manifest in humanity's common possession of nature's abundance in Paradise $\left(\right.$ Or. 14.25) ${ }^{12}$ and exhorts "to look back on humanity's

11 Translation comes Divine Institutes (tr. and intro. A. Bowen and P. Garnsey; Liverpool: Liverpool University Press, 2003).

12 Cf. John Chrysostom, Hom. Ion 15.3; Theodoret of Cyrus, Prov. 6.25. 
original equality (isonomia)" in creation, "not the later distinction" (Or. 14.26). ${ }^{13}$ Like Lactantius, Gregory advances God's justice (isotes) (Or. 14.24) and human equality (isonomia) as two indispensable aspects of creation and human flourishing. While God's justice or fairness establishes a standard of God's compassionate generosity (philanthrōpia) in creation, providence, and incarnation, the original human equality manifests in both our common ontological and spiritual dignity and physical need in our materiality. We, created in the image (eikon) of God, are all endowed with rational power, power to know God, to hope for the Kingdom of Heaven and for the vision of glory, to reign over all things on earth, and to become divine (Or. 14.20, 23). We are also alike in our earthly wretchedness and bodily weaknesses, "so all look towards our hands as we look towards God's, for the things we need" (Or. 14.6; cf. 14.27). This twofold equality then binds us together in common human nature and solidarity, which leads to: first, "love of the poor, and compassion and sympathy for our own flesh and blood", as "the most excellent form of virtue" (Or. 14.5); and second, "love of humanity" (philanthrōpia) shown towards our fellow men and women, particularly those with leprosy, as "the single way towards the salvation both of our bodies and of our souls" (Or. 14.8). Thus, Gregory likewise integrates God's justice, human equality, and philanthropia, which together bind both vertical and horizontal relationships; both justice and equality manifest in philanthrōpia as a mirror (eikon) of the divine in humanity for human flourishing. Therefore, he urges Christians: "As far as you can, support nature, honor the original freedom, respect yourself, cover the shame of our race, assist those with sickness, and aid those in need" (Or. 14.26).

\subsection{Providence, Redistribution, and Human Flourishing}

As seen in Lactantius and Gregory of Nazianzus, the patristic authors wrestled with socio-economic inequalities and unequal distribution of wealth and possessions in relation to human flourishing. How can God be provident and at the same time allow such apparent injustice and anomalies to continue? Whereas Lactantius spiritualized equality and saw socio-economic diversity compatible with Christianity, Gregory, while also spiritualizing equality, regarded socio-economic inequality as a result of human greed and a symptom of creation's fall-a gross deviance from God's creative and eschatological justice (Or. 14.25). ${ }^{14}$ However, for both, as for other patristic authors, the uneven distribution of wealth and possessions was the very opportunity and context in which those with greater possessions ("the rich") should exercise distributive justice in imitating God's justice and philanthropia. Refuting a deep-seated classical and even Christian notion that blames the poor for their poverty and suffering and that praises the rich for their prosperity as God's will, Gregory enjoins "the healthy [to] help the sick, and the rich [to] assist the poor ... [thus to b]ecome a god to the unfortunate by imitating the mercy of God" (Or. 14.26). Those who exercise compassionate generosity (philanthrōpia) to the sick and the poor share in God's work of salvation and compassionate Providence, reversing the effect of the fall $(\mathrm{Or} .14 .35,33,26) .{ }^{15}$ Thus, the acts of philanthropia are the means of restoring divine image and primal freedom in individuals, and divine justice and human equality in creation, in other words, human flourishing.

John Chrysostom strongly affirms and goes further than Gregory's assessment of the anomalies of socio-economic inequalities. Their root and origin must be injustice of the rich since "God in the beginning made not one rich and another poor ... [but] left the earth free to all alike" (Hom. 1 Tim. 12.4).${ }^{16}$ Even the inherited riches, which were usually thought immune to a charge of ill-gotten wealth, cannot escape the charge of injustice; for the rich have to trace their inherited wealth back to the

\footnotetext{
Translation of Gregory's text in this paragraph is mine.

4 See also Basil Hom. 6.7.

Cf. Basil, Hom. 8.7.

16 Translations used in this paragraph are mine. Cf. Ambrose, De Nab. 1, 2: "Earth at its beginning was for all in common, it was meant for rich and poor alike; what right do you have to monopolize the soil? Nature knows nothing of the rich; all are poor when she brings them forth" (my translation); also, De off. 1.28.132.
} 
original acquisition of their ancestors, which must have involved greedy and unjust acquisition from the common belongings from God's creation (12.4); simply put, "to grow rich without injustice is impossible" (12.3). Therefore, the rich are squarely responsible for the unequal distribution of wealth and perpetuating that injustice through their greed, hoarding, and luxury. ${ }^{17}$ As such then, they can and should reverse this injustice, redeem their goodness, and restore the goodness of wealth: "When they [the rich] distribute their riches, they are good, so that they are good when they have ceased to have it, when they give it to others ... [T] he more charitable [they] are, the more good [they] will be considered" (12.4). Chrysostom returns to the social purpose of wealth: since wealth is not a property but only a loan for use, it "is not bad or evil if [the rich] are not avaricious and distribute to the poor" (12.4). Although God could have taken away the rich's possessions from them, God "left them so that you may have the opportunity to show forth virtue. Thus, bringing us into need one of another, he makes our love for one another more fervent" (Hom. Matt. 77.6). Their almsgiving for the poor is the only means to undo their crime of inhumanity, retain a Christian identity and virtue, and thus to restore a semblance of God's creative intent for the common good (cf. Hom. Laz. 2.4; Hom. Acta 20.4).

However, for patristic authors such as Clement of Alexandria, Augustine, and Theodoret of Cyrus, God the Creator indeed allots wealth to some and poverty to others in God's sovereign providence (cf. Lactantius). ${ }^{18}$ Theodoret of Cyrus, responding to critics and skeptics of God's providence, frames the issue in terms of the common good using the apostle Paul's body analogy in 1 Cor. 12. ${ }^{19}$ Just as God has given different faculty to various members of the body, different levels of wealth among individuals contribute to the good and advantage of the community as a whole (Prov. 6.17-19). In fact, while the rich and the poor do share spiritual equality and undergo the same kind of life cycle (e.g., marriage and pregnancy), the very inequality of wealth is the foundation of a sound economy and interdependence, necessary for human flourishing: we need servants, cooks, bakers, butchers, potters, and masons, as there are those who eat delicacies, live in well-designed houses, and need the services and necessities of life (Prov. 6.22-25). The rich supply money and the poor (i.e., penettes: those who work with their hands for a living) provide the fruits of their trade (Prov. 6.33), as the latter work with the very raw material of wealth such as gold, silver, and bronze that sustain the former (Prov. 6.34). Theodoret here envisions a well-functioning society with complementary needs of the rich and the poor that necessitate and sustain their symbiotic and harmonious relationship in fulfillment of mutual needs (Prov. 6.34-35). Framing human flourishing in this way, Theodoret presents wealth and poverty only as raw materials placed before people by God. He is not so concerned about the origin of wealth and poverty like the Cappadocian Fathers and John Chrysostom as their function and use; and it is on the latter that he can place human responsibility while protecting God's providence. Certain people "use them to acquire virtue, others made them the foundation of wickedness, but neither wealth nor poverty is in itself an excuse for evil living" (Prov. 6.37). The very reality of "the pious poor and the wicked rich" in the present presupposes and displays free will, God's highest gift to humans, that makes this model of human flourishing possible within God's providence (cf. Prov. 6.36). Proper and purposeful administration of their wealth by the rich (i.e., sharing it with those in need) and courageous and patient endurance of their poverty by the poor silence attributing evil to God, uphold God's justice and mercy, and confirm the life of virtue.

\subsection{Salvation, Virtue (Self-Care), and Wealth and Poverty ${ }^{20}$}

In the aforementioned framework of human flourishing in creation and sociability of material goods in patristic thought, it has already been evident that cultivation of social virtue of philanthrōpia ("love of humanity" through compassionate generosity) both constituted and exhibited human

\footnotetext{
Cf. Anonymous Pelagian author, De divitiis 8.1-4.

See Clement, Quis div. 26; Augustine, Serm. 367.3; 61.9.10; 14.8.

For a recent study on wealth and poverty in Theodoret, see (Gotsis and Merianos 2007, pp. 11-48).

Parts of this section on Clement of Alexandria and Cyprian are revised from (Rhee 2012, pp. 77-82, 96-97, 99-100).
} 
flourishing. It has also been evident that the virtue of philanthropia was the attendant virtue of salvation (the goal of creation, including humanity), in reversing the effects of the fall and restoring human flourishing. As we probe deeper into an internal and individual dimension of flourishing, we find patristic authors concerned about how wealth presents Christians with a unique challenge and opportunity to demonstrate their spiritual state and persevere in their salvation by eliminating vices and cultivating virtues, and thereby to affirm and confirm their Christian identities.

When patristic authors address or make references to wealth (and poverty), it is typically directed to Christians who are already on the journey of Christian faith and yet must persevere to the end. ${ }^{21}$ As a "seal" of salvation that brings about remission of sins, rebirth, and the gift of the Holy Spirit, ${ }^{22}$ baptism marks a new beginning of a life-long upward journey toward maturity and perfection in imitation of God which requires constant vigilance, discipline, struggle against temptations and vices, and cultivation of virtues until the end. ${ }^{23}$ In order not to fall from grace after baptism, a Christian must refrain from sin and progress in sanctity by assiduous disciplines and good works. ${ }^{24}$ Tertullian's characteristic way of understanding this life of salvation is consistency between inner reality and virtue of Christianity and its outer expression and conduct/lifestyle. ${ }^{25}$ The salvific faith must show itself in the world and carry an exact external or visible form, otherwise it is not faith at all. ${ }^{26}$ Clement of Alexandria presents Christian salvation more explicitly as a two-stage spiritual and ethical process of self-care: first, a struggle with and cure of pleasure (hēdonē), passion (pathos), and desire (epithumia) through purification and self-control (autarkeia and metriopatheia) (Strom. 6.105.1 [2.484.29]), ${ }^{27}$ eventually moving on to, second, a perfect state of passionless contemplation and imitation of God (apatheia) where the snares and traps of desire are no longer dangers to the soul (Strom. 6.7.1ff [2.467ff]; 6.71.3-72.1). ${ }^{28}$ With baptism every believer embarks on a long, arduous and upward journey of healing of passions (Paed. 1.36.2.4; 1.43.1; 2.100.3), and an advanced baptized believer should grow and develop to reach the perfect gnostic state. As Harry Maier aptly puts it, for Clement, "[ $\mathrm{t}]$ he redeemed self is engaged in a life and death struggle [agōn] with the old sinful self of the passions" and cultivates freedom by applying the law and Christ's truth, ${ }^{29}$ this struggle itself testifies to the salvation of the self. ${ }^{30}$

\subsubsection{Detachment, Greed (Love of Wealth), and Luxury}

Expounding on the Markan account of the "rich young man" (with a Matthian text of 19.21), Clement of Alexandria in his famous treatise Who is a Rich Man that is Saved? (Quis dives salvatur), internalizes the young man's problem for his wealthy Alexandrian audience. To the rich man's quest for eternal life, Jesus apparently demanded dispossession of his wealth and ultimately declared a virtual impossibility of the rich entering the Kingdom of God as the rich. Is there hope for the rich? If so, how can they be saved? Using a figurative interpretation, he internalizes salvation as that which "does not depend upon outward things" but upon the "soul's virtue" (18); purging oneself of the soul's passions is the key to entering the kingdom of God. Since the rich man's fulfillment of the law was good but not perfect, ${ }^{31}$ Christ's counsel of perfection to the rich man, i.e., to sell his possessions, does

21 E.g., Tertuallian, Praescr. 3.6; Clement of Alexandria, Quis div.1-2; John Chrysostom, Hom. Matt. 12; Hom. 1 Tim. 11; 12; Augustine, Ep. 130, 157; En. in Ps. 38.

22 Paen. 7.10. Cf. other contemporary Christian understandings of baptism, e.g., Hermas, Vis. 3.3; Sim. 8.2.2; Mand. 4.3; Sim. 9.13; Justin, Ap. 1.61; Theophilus, Autol. 2.16; Origen, Hom. Lev. 2.4.5; Acts Paul 25; Acts Thom. 121.

23 Cf. Clement of Alexandria, Strom. 6.105.1; 6.71.3-72.1; Quis. div. 3, 40; Origen, Hom. Josh. 1.6; Or. 29.13.

24 E.g., Tertullian, Paen. 7.10; Pud. 1.10.

25 (Groh 1971, p. 13).

26 (Raditsa 1985, p. 305).

27 Cf. (Maier 1994, p. 728).

28 Cf. (Maier 1994, p. 734).

29 (Maier 1994, p. 732)

30 (Maier 1994, p. 728). Cf. Similarly, salvation for Origen is essentially an education in divine training and guidance, in which "God orders every rational soul with a view to its eternal life ... until it reaches the pinnacle of virtue" with its free will (Or. 29.13); see also (De Faye 1929, p. 128).

31 Cf. Strom. 3.6.55.2. 
not mean any external act of divestment but rather inner detachment: "to strip the soul itself and the will of their lurking passions and utterly to root out and cast away all alien thoughts from the mind" (11). If the Savior's words were to be taken literally, they are no more than an extension of the law, which is external and therefore "no life-giving" (9), and no more than a reiteration of what the Greek philosophers have already done prior to his coming (11). Therefore, Christ's teaching must be "more divine and more perfect", new and unique, superseding all human teachings before him (12). Thus, it cannot mean the literal renunciation of wealth, which points to mere natural human capacity. In fact, the literal renunciation of wealth does not actually cure the disease of the soul; instead, it could rather create a "double annoyance, the absence of means of support and the presence of regret" simply due to basic human needs (12). Therefore, it could result in false pretension of cure riddled with even greater passions and anguish. Both voluntary and involuntary poverty have no intrinsic value apart from attendant poverty of the soul, which is available for the rich as well as for the poor. ${ }^{32}$

This internalization of salvation and Christ's commandment demystifies the traditional assumption of "the pious poor and the wicked rich" and spiritualizes wealth and poverty. ${ }^{33}$ As Clement deconstructs the pious poor and the wicked rich tradition, he constructs a model of the pious rich and the wicked rich on the one hand and the noble poor and the wretched poor on the other. The pious rich are the ones who are "rich in virtues and able to use every fortune in a holy and faithful manner" (19); they are contrasted with the "spurious rich" who are "rich according to the flesh" but pursuing the life of transitory outward possessions (19). Likewise, the genuine poor (ptōchoi) are the ones who are "poor in spirit" with "the inner personal poverty" whereas the spurious poor consist of the poor "in worldly goods, the outward alien poverty" but full of vices (19). Clement in this way connects the true, pious rich with the genuine, spiritual poor and shows how "the same man can be both poor and wealthy" (20). Christ's call to "sell one's possessions" then is a universal call not only to the spurious, outwardly rich but also to the spurious, outwardly poor to detach themselves from the "alien possessions that dwell in [their] soul[s], in order that [they] may become pure in heart and may see God" (19). This is, in fact, what St. Peter exactly demonstrated in his life. When he said, "Lo, we have left all and followed [Christ]", he meant "by flinging away the old possessions of the mind and diseases of the soul that [the disciples] are following in the track of their teacher" (21). This is indeed how one follows the Savior: that "we seek after [the Savior's] sinlessness and perfection, adorning and regulating the soul before Him as before a mirror and arranging it in every detail after His likeness (homoiōsis)" (21). ${ }^{34}$ Again, salvation in this paradigm is passionless imitation of Christ, ${ }^{35}$ overcoming the insidious inner persecutions-godless lusts and manifold pleasures, and covetousness (25). This is the life of a true gnostic, which is the costly result of the disciplined care of the self (heautou epimelonmenos) ${ }^{36}$ and can never be achieved by a single act of external renunciation.

As Clement and patristic authors primarily see the effect of possessions in terms of one's attitude toward one's own possessions, the greatest challenge to achieving this inner detachment and self-care, which is necessary for salvation, is greed or love of wealth. It is fundamentally incompatible with philanthropia. Merging a moral and theological problem together, they construct the problem of avarice (love of money: pleonexia, philargyria, avaritia, cupiditas) essentially as idolatry ${ }^{37}$ and thus something intrinsically antithetical to Christian faith and identity with external (social) consequences.

Tertullian deals with greed (cupiditas) - "the desire of money" [1 Tim. 6.10]—in the context of addressing Christian patience in the face of many ills in life, including the loss of property. On the one hand, Jesus, who himself was poor and always justified the poor and condemned the rich, is a

32 Cf. Augustine, Nuova Biblioteca Agostiniana (NBA), 31/1, 104.

33 Augustine closely follows Clement in spiritualizing wealth and poverty, and the rich and the poor in Serm. 114B; $346 \mathrm{~A}$; En. In Ps. 48; Serm. 1.3; 53A.

34 Cf. Strom. 2.131.5; 2.97.1.

35 Cf. Strom. 2.326.3ff.

36 Strom. 7.16.1.

37 Cf. Col 3.5; Tertullian, Idol. 11.1. 
model of patience through his indifference toward money (7.2-3). On the other hand, greed is an acquisitive spirit, which by nature is never satisfied with one's own but always crosses a boundary of one's "private property" for something that belongs to another and to God (7.5). If Christians are unable to bear their material loss, they "will be found to possess a desire for money, since [they] grieve over the loss of that which is not [their] own" (7.6). In that case, they sin against God and behave like pagans by confusing the priority of heavenly goods over earthly goods $(7.7,11)$; for greed is essentially an offence to God's sovereign ownership and a false and pretentious claim to our non-ownership. Then, an impatient Christian behaves like a pagan by prioritizing earthly goods over heavenly goods and thus exhibiting a serious attachment to the world (Pat. 7.11) which manifests in reluctance in almsgiving (to the needy) (Pat. 7.8); but patience to endure loss is a "training in giving and sharing" since the one "who does not fear loss is not reluctant to give" (Pat. 7.9). Therefore, just as patience is a virtue that defines the Christian's relationship with God and his/her "neighbors", impatience in loss is a vice that disrupts and eventually destroys both vertical and horizontal relationships. It only befits Christians "to give up not our life for money but money for our life, either by voluntary charity or by the patient endurance of loss" (Pat. 7.13).

For Cyprian of Carthage, greed had collectively fatal consequences. As the Decian persecution of 250 and 251 caught the churches off-guard and demoralized them to internal chaos and crisis that escalated eschatological anxiety, ${ }^{38}$ Cyprian in On the Lapsed (251 CE) saw the persecution (however evil it may $\mathrm{be}^{39}$ ) rather as God's testing of God's household that had been growing complacent in the years of peace (Laps. 5). He blames a cause of the persecution (God's testing) and mass apostasy on the rich believers' "insatiable greed" (insatiabili cupiditatis) and "blind attachment to their patrimony (patrimonii sui amor caecus)" to the neglect of generous charity for the needy $(5-8,11)$. Cyprian speaks of them as slaves to profit and money, tethered to the chain of their wealth (12). During the persecution, the rich honestiores would have been the more visible target of the authorities because of their socio-political position and property. ${ }^{40}$ Nonetheless, they should have confessed Christ by letting go of their properties and withdrawing to exile, Cyprian writes (10). Yet many wealthy Christians did not follow that expected course of action but instead complied with the edict on behalf of entire households ${ }^{41}$ and thereby sought to protect their dependents and properties (8). Others avoided the actual act of sacrifice and therefore regarded themselves guiltless by obtaining the certificates of sacrifice (libelli) by proxy or bribery ${ }^{42}$ or purchasing forged certificates either in person or by agents (27). Apparently, this was an attractive option because it was a clever way to keep their Christian commitment and to keep their properties and position-or so they thought. However, Cyprian considered such fictive certificates as "confession of apostasy" and regarded both groups—sacrificers (sacrificati) and the certified (libellatici)—as the lapsi $(8,27) .{ }^{43}$ Even in times of peace, says Cyprian, the rich who preserve their worldly wealth while neglecting the want of the poor sin gravely with their covetousness and can only expect eternal loss and punishment like the rich fool in the Lukan Gospel (Eleem.17). One should remember that Christ himself taught the contempt and perils of riches as they contained the root of all evils (Dom. or. 20).

In the post-Constantinian situation where the church was given the task of caring for the poor of the empire, Basil focuses on greed and its social impact in his famous Homily 6 (I Will Tear Down

38 On the relationship between wealth, poverty, and eschatology, see (Rhee 2011, pp. 64-84). On Cyprian's ministry to the poor in the context of the rigorist-laxist schism in Carthage, see (Dunn 2004).

39 Demetr. 12, 17.

40 It would have been so especially if the authorities used a census roll with registered property (for tax)—however haphazardly. Probability of the use of Caracalla's citizenship census (Constitutio Antoniniana, 212 CE) for taxation purpose is strongly suggested by A. Brent (2010, pp. 197-247), and W. H. C. Frend (1986, p. 408). Contra G. W. Clarke (1969, pp. 48-73); idem, The Letters of St. Cyprian of Carthage (ACW; Vol. 1; New York: Newman, 1984), pp. 26-28.

41 Cf. Cyprian, Ep. 55.13.2; Laps, pp. 27-28.

42 Cf. Cyprian, Ep. 30.3.1; 55.14.1.

43 Cyprian treated the certified more sympathetically in Ep.55.14.1-2; on the problem of the certified in the Roman church, see Ep. 30.3.1. 
My Barns) and Homily 7 (To the Rich). In Homily 6, expounding on the Lukan parable of the rich fool who wished to enlarge his barn for the excess harvest (Luke 12.16-21) ${ }^{44}$ Basil zeros in on the insidious effect of accumulation of wealth and its superfluidity not only on the possessor but also on the whole community around the possessor. The rich fool's greed is reflected in his agony over storing the overflow of his wealth and feeling "still more wretched by the greater abundance he still expected to receive" (Hom. 6.1). As C. Paul Schroeder perceptively points out, in Basil's treatment "tearing down one's barns becomes a metaphor for describing an expanding baseline of need" based on "a change in one's circumstances". ${ }^{45}$ This then becomes a constant excuse for not sharing surplus wealth (i.e., possessions beyond necessities) with others for the rich since they keep adjusting their definition of need to suit the new situation of overflow (Hom. 6.1). In his obsession with the care of over-abundance, the rich fool is completely oblivious to the fact that he is only a steward of God, who is his benefactor, and shares a common nature with the poor; thus, he is impervious to the groans of the needy and the social purpose of wealth granted by God's Providence $(2,4,7)$. Avarice always leads to and manifests in pride and selfishness, which always has spiritual and social consequences, and Basil directly links them to the misery of the poor.

In Homily 7, avarice, idolatrous and irrational lust of money or wealth, goes hand in hand with luxury, ${ }^{46}$ an idolatrous and irrational display of one's wealth, manifesting the same heinous pride and selfishness. Addressing the rich Christians, Basil indulges in describing a "sickness" of avarice and ridiculous and outrageous displays of luxury among the refined elites: from the number of carriages, horses, servants, obsession with precious metals such as gold and silver, clothing, sumptuous meals and decorations, to jewelries and ornaments (Hom. 7.2, 4, 7; Hom. 6.4, 5) ${ }^{47}$ Expounding on the familiar Matthian account of the rich young man (Matt 19.16-22), Basil interprets the young man's failure to "sell [his] possessions and give to the poor" as greed that results in the rich's excessive consumptions and their competitive but destructive "race for supremacy" (5). Their addiction to wealth deceives them to act like beggars, constantly asking for more. In both sermons, Basil highlights the unnatural and thus degenerate nature of avarice and luxury in violating nature and the social purpose of wealth, which leads to crimes of misanthropy:

They seize what belongs to all and claim the right of possession to monopolize it ... Who is a covetous one? One for whom sufficiency is not enough! Who is the defrauder? One who takes away what belongs to everyone. And are you not covetous, are you not a defrauder, when you keep for private use what you were given for distribution? (Hom. 6.7) ${ }^{48}$

Therefore, in their superfluidity and luxury, the rich commit not only a "sin of commission" (avarice, pride, self-love, and attachment to the world), but also a "sin of omission" by neglecting the commandment of loving one's neighbor as well as a "sin of oppression" through their robbery and theft of common resources. ${ }^{49}$ The very existence of the needy and the poor (yes, there are many who are in need) testifies to an outrage of idle surplus and self-gratifying luxury, especially in its social ramification (Hom. 6.1, 7; 7.5).

For Augustine, his central distinction between "use" (uti) and "enjoyment" (frui) in De doctrina christiana dictates his understanding of wealth and the problem of greed as misplaced desire for wealth. Material goods and wealth are to be only a means (uti) to obtain the true object of our desire (frui-e.g., eternal life, eternal happiness, ultimately God) in the hierarchy of goods, not the other way

44 On Basil's principle of detachment from private property in Homily 6, see (Matz 2011, pp. 161-84).

45 On Social Justice: St. Basil the Great (tr. and intro. C. Paul Schroeder. Crestwood, NY: St. Vladimir's Seminary Press, 2009), p. 28.

46 See Clement of Alexandria, Paed. 2.3.38-39; Paed. 3.3.21.

47 See also Clement of Alexandria, Paed. 2.3, 8, 11-13; Gregory Nazianzen, Or. 14.16-17.

48 Cf. Clement of Alexandria, Paed. 3.7.37: "Love of wealth displaces a man from the right mode of life, and induces him to cease from feeling shame at what is shameful".

49 Cf. Clement of Alexandria, Paed. 3.6.34-36; 2.13.120, respectively. 
around. Virtue consists in enjoying (frui) and clinging to what is eternal and spiritual for its sake and using $(u t i)$ what is material and temporal well without loving or clinging to it, whereas vice is mixing up and reversing the order. An example for the former is described in one of his sermons: "What does gold say to me? 'Love me'. But what does God tell me to reply? 'Let me use you, and so use you that you don't possess me, and that you part me from you'" (Serm. 65A.4). In the case of vice, we risk being driven away from the proper object of our desire (God) by "false pleasure" camouflaged in our disordered love (i.e., avarice) (De doc. chr. 1.3.4). In this paradigm, since Augustine defines avarice as the desire to be wealthy rather than the actual possession of it, the rich and the poor, are both capable of virtue and vice, depending on their dispositions to wealth and poverty (Serm. 8.6). As in Clement of Alexandria, this means that poverty does not guarantee virtue and that wealth is not necessarily the vice; Abraham and Job exemplify the righteous rich. ${ }^{50}$ Like Basil, here Augustine closely links avarice to pride, which is the primal $\sin ^{51}$ and applies them to both the rich and the poor. Therefore, as with Clement (but unlike Basil), Augustine spiritualizes the rich and the poor and understands wealth and poverty in terms of inner disposition. ${ }^{52}$ Furthermore, in terms of the relationship between the possessions and the possessors, people do not become virtuous by their possessions, but the goods (e.g., riches, positions, honor, etc.) become good in the hands of the virtuous only as the latter make good use of the former for the sake of the true (heavenly) life. ${ }^{53}$ Conversely, the use of wealth in a bad way is the wrongful use of wealth and as such deprives the possessor of his or her "right" of ownership; the possessors' "claim to just possession is the proportion to their indifference to wealth" (Ep. 153.26).

\subsubsection{Detachment, Almsgiving, and Salvation}

If greed and luxury, which manifest in various contexts and ways, are the principal vices against salvific self-care and detachment from wealth, almsgiving, the expression of philanthropia, is the essential practice necessary for detachment and thus salvation. The patristic authors present consistent yet developing theology of "redemptive almsgiving" in their specific contexts. ${ }^{54}$ Returning to Clement's Rich Man's Salvation, his main concern is how the Christian rich can arrive at the perfect, gnostic state using their wealth, which is through almsgiving. For Clement, the theological ground for almsgiving is the greatest commandment of loving God and loving one's neighbor as oneself (27-29; cf. Matt 22.36-37). By giving relief to fellow Christians in need (31), the rich love Christ as their neighbor as they love God; and they fulfill Christ's injunction to make friends with unrighteous mammon for their eternal life (Lk 16.9) and secure their heavenly reward (31). In so doing, the rich should not just "yield to a request or wait to be pestered" but "should personally seek out men whom [they] may benefit" for their progress toward salvation, "men who are worthy disciples of the Savior" (31). Thus, Clement champions the redemptive effect of almsgiving in the following way:

What splendid trading! What divine business! You buy incorruption with money. You give the perishing things of the world and receive in exchange for them an eternal abode in heaven ... Spare not dangers or toils, that here you may buy a heavenly kingdom. (32)

Giving to the poor Christians promises a sure return of abundant reward and spiritual wealth to the rich to the extent that Clement freely uses an economic language of transaction and exchange-a notion already heavily featured in the Shepherd of Hermas. However, Clement qualifies this great exchange: the rich should see to it that 'the Lord did not say, 'give', or 'provide', or 'benefit', or 'help', but 'make a friend'" (32). Just as ridding one's soul of passions takes a continual struggle and training,

\footnotetext{
Serm. 1; 346A; En. in Ps. 85.3; 132.5; Ep. 157.23-24.

Civ. Dei 14.13; Gn. litt. 11.15.19. Cf. Basil, Hom. 6; Hom. 7.

See (Ramsey 1999, pp. 878-79; Allen and Morgan 2009, pp. 144-45).

Ep. 130; Serm. 72.4; 61.2; 301A; cf. 48.8.

54 On this topic of redemptive almsgiving, see (Garrison 1993; Finn 2006; Anderson 2007, pp. 39-67; Anderson 2013; Downs 2016).
} 
making friends with one's wealth and building relationships with the recipients of their alms take sustained work. Furthermore, in doing so, the rich should not try to distinguish the worthy from the unworthy poor for God and Christ dwell within the poor (33). ${ }^{55}$ What is necessary and important for the rich is to find those among their recipients "who have power to save [them] with God" as they give to all who are enrolled as God's disciples, i.e., the Christian poor in general (33). What is noteworthy is the fact that contrary to his earlier effort to deconstruct the tradition of "the pious poor and the wicked rich" in interiorizing and spiritualizing wealth and poverty, Clement presupposes and counts on that very tradition here in promoting redemptive almsgiving for the rich Christians. The pious poor's role for the rich in the church is absolutely vital, and their effectual spiritual services are both specific and comprehensive: "One is able to beg your life from God, another to hearten you when sick, another to weep and lament in sympathy on your behalf before the Lord ... " (35).

If one-time renunciation would not be a solution for the salvation of the rich, then on-going generous almsgiving is a palpable way to obtain their salvation as a necessary part of the care of the self. Redemptive efficacy of almsgiving is rooted in the reciprocal exchange of love among believers, which is in turn rooted in God's love and a reciprocal demand of Christ's sacrifice (37). In this sense, almsgiving is a quintessential, positive demonstration of loving God and neighbor as well as of using one's wealth properly. With an unabashed appeal to self-interest of the rich giver, ${ }^{56}$ a more fundamental appeal for almsgiving is love of God and love for God, without which no one can gain salvation (cf. 38). Through consistent and generous almsgiving, the rich cultivate inner detachment and freedom as the race to salvation takes a laborious training and perseverance $(3 ; 40) .{ }^{57}$ Because God receives and forgives everyone who turns to him in genuine repentance, almsgiving is an effective means of repentance and rooting out of the soul the post-baptismal sins leading to death (39). The heavenly Father will give the earnest rich "true purification and unchanging life" (42).

Tertullian takes up almsgiving and salvation of the rich in his massive work, Against Marcion where he defends the fundamental unity of God in the Old and New Testaments as both the Creator and the Redeemer against Marcion's dichotomy between the two and radical asceticism in rejection of the material world. Commenting on the discourse between Jesus and the rich young man (Lk 18.18-22) who asked Jesus, the "Good Teacher" of God's commandment, how he could obtain eternal life, Tertullian indicates the significance of Jesus' answer in pointing the rich man to the "Creator's commandments [pl.], in such form as to testify that by the Creator's commandments [pl.] eternal life is obtained" (4.36.4; italics added). ${ }^{58}$ To the rich man's answer that he had kept them since his youth, Christ did not rescind those former commandments (the Decalogue) but "both retained these and added what was lacking", namely, selling all that he had and giving to the poor (4.36.4-5). ${ }^{59}$ "And yet", Tertullian writes, "even this commandment [sg.] of distributing to the poor is spread about everywhere in the law and the prophets", so that it led to "the boastful commandment-keeper's" conviction of "having money in much higher esteem" and, therefore, not to his attainment of salvation (4.36.5; italics added). In this context, Tertullian's idea of God's commandment [sg.], without which eternal life could not be obtained, is precisely "distributing [one's possessions] to the poor" and, with that addition, Jesus "both conserved and enriched" the Decalogue and proved that he fulfilled the Mosaic law (4.36.6). By "distributing to the poor", Tertullian does not mean literal abandonment of wealth (voluntary

55 This understanding of Christ in the poor, based on Matt. 25.31-46, would be a key common element especially in the post-Constantinian exhortations to almsgiving with a universal application to all poor, including the lepers (not just the Christian poor). See the last paragraph of the main body. Cf. B. Ramsey (Ramsey 1982, pp. 226-59). On the close relationship between the care of the poor and the doctrine of the Incarnation, see (Holman 2009, pp. 25-26, 41).

56 On this topic, see (Downs 2016, pp. 275-77).

57 Cf. Paed. 3.6.34-36.

58 On Tertullian's interpretation of Luke 17.21 and of almsgiving as God's commandment leading to the kingdom/eternal life in the story of a rich ruler in Luke 18, see (Michaels 1998, pp. 479-83).

59 Compare "all that you have" [quaecunque habes] in 4.36.4 with "what you have" [quae habes] in 4.36.7. 
poverty) but almsgiving. Thus, almsgiving fulfills both doing justice and loving mercy of Micah 6.6 and the "one thing" required by Christ for salvation (4.36.7; cf. 4.27.6-9).

For Cyprian, the "apostolic solution" to the (wealthy) lapsi was to scorn worldly possessions and leave them for the kingdom of God and heavenly compensation (Laps. 12). The (wealthy) lapsi, as the sign of true repentance, should apply themselves to "just deeds [iustis operibus] which can wash away [their] sins, be constant and generous in giving alms, whereby souls are freed from death" (35). In the new dire situation of the dreadful plague that swept through Carthage with such great force (summer, 252), Cyprian augmented his theological argument for almsgiving in On Works and Alms (De opere et eleemosynis). ${ }^{60}$ It was another demoralizing blow to Christians who had just gone through the imperial persecution and especially those Christians who felt that the sweeping deaths by the plague had stripped (or would strip) them of the possibility of either a second chance for salvation (reconciliation) or perfection through martyrdom. ${ }^{61}$ Cyprian addressed their anxiety and pessimism and highlighted another way to purge sin other than martyrdom-not as heroic as martyrdom but certainly effective: almsgiving to the poor (Eleem. 6). ${ }^{62}$ Out of his great compassion, God himself "labored" for our salvation through the advent and death of his Son Christ but his providence also provided for his people remedies for sin "after [they were] already redeemed!" (Eleem. 1):

Nor would the infirmity and weakness of human frailty have any resource, unless the divine mercy, coming once more in aid, should open some way of securing salvation by pointing out works of justice and mercy (iustitiae et misericordiae operibus), so that by almsgiving we may wash away whatever foulness we subsequently contract (ut sordes postmodum quascumque contrahimus eleemosynis abluamus). (Eleem. 1 ; italics added)

Note Cyprian's understanding of the inner logic of salvation and almsgiving. For Cyprian, far from almsgiving being a human work in danger of threatening or supplanting the divine work of salvation, it was God's own mercy and design that he provided for us this particular way-out for our post-baptismal sins. Almsgiving and Christ's death never compete with each other and the former does not undermine the salvific significance or sufficiency of the latter. Both are the expressions of God's abundant grace, condescension, and providence, and it is only by God's grace that almsgiving can be meritorious and satisfactory in his sight $(1,2,5){ }^{63}$ In this sense, almsgiving (i.e., "works of righteousness") becomes "the likeness of baptism" because "in baptism remission of sins is granted once for all" (2). However, the difference between baptism and almsgiving is that the former is non-repeatable for forgiveness of sins and formal entrance to the church, ${ }^{64}$ but almsgiving is not just repeatable but requires "constant and ceaseless labor" for remission of sins and readmission to the church $(2,24){ }^{65}$

In this way, Cyprian preemptively deals with the rich Christians' possible excuses from and objections to almsgiving and links right motive of almsgiving squarely to their hope of heavenly glory. Like Clement of Alexandria and the author of the Act of Thomas, Cyprian audaciously describes it as an economic transaction; givers of alms are "merchant[s] of the heavenly grace" whose gain is none other than eternal life (7) in partnership with Christ (13) and who make God their debtor (15, 16,

60 For the most recent study on almsgiving in this work, see (Downs 2016, pp. 256-70).

61 Mort. 17. Cf. Sage (1975, p. 273). Although the early church generally opposed voluntary martyrdom, it made an exception for the lapsed Christians who needed to "wash away their former fault" (apostasy) through offering themselves up for martyrdom and Cyprian himself attested to its occurrence (Ep. 24); see also Ep.19.2.3; Laps. 36.

62 Cf. Sage (1975, p. 273)

63 Cf. Clement of Alexandria, Quis div. 37.

64 Cyprian later changed (at least clarified) his position on the validity of baptism received in a schismatic church (the Novatian church) during his baptismal controversy with Stephen of Rome. Cyprian insisted on "rebaptism" of the schismatic upon their readmission to the Catholic church since they forfeited the Holy Spirit due to their schism; but Stephen recognized validity of schismatic baptism and required only reconciliation with laying on of hands, since baptism should not be repeated.

65 Cf. Clement of Alexandria, Quis div. 32. 
26). ${ }^{66}$ And this God in turn will never fail to pay divine wage for their labors (23), that is, "a white crown" in peace as an equivalent to a purple one for martyrdom during persecutions (26). Although Cyprian rarely condemns wealth as such and advocates its divestment, he, like his fellow North African Tertullian, does take Jesus' words to the rich young man (Matt 19.21) literally, in contrast to the Alexandrians: "the Lord tells us that he becomes perfect and complete who sells all his goods, and distributes them for the use of the poor, and so lays up for himself treasure in heaven" (Dom. or. 20). Ultimately for Cyprian, almsgiving as life-long penance provided an absolutely necessary (pre-)condition for and with the reconciliation of the lapsed; and their "conspicuous almsgiving" was a means that should sustain the care of the poor in the financially strapped situation of his congregation. Thus, as William Countryman fittingly expresses, earthly "riches offered the remedy for the very harm they caused" for the wealthy. ${ }^{67}$

Building on these foundational theologies of almsgiving, Basil's approach to almsgiving, shared by other post-Constantinian church fathers, is more geared toward its social impact just as he was concerned about the social impact of greed and luxury. In Homily 6, Basil presents almsgiving as the way to build an alternative barn in which the rich can store their heavenly treasures $(5,6)$; the rich store and secure their inexhaustible heavenly treasures by dividing up and distributing their earthly harvest to the hungry, the naked, and the debtors (6). Then, it is the way for the rich to acknowledge God as their benefactor and God's philanthropy for creation and for them to honor nature's bounty as it produces its fruit for the benefit of all $(1,3)$. Therefore, through giving alms, the rich understand and realize the social purpose and use of wealth in God's providence and can enter the heavenly kingdom $(7,3)$. Similarly, in Homily 7 Basil emphasizes almsgiving as the best and most secure preparation for judgment and for restoration of true humanity $(9,5)$. As the ideal of primal common ownership, sharing and equality for the common good governs his understanding of human flourishing. Basil also presents it as the means to undo the primal sin of selfishness and usher in the new creation with cosmic significance in his Homily 8 (In Time of Famine and Drought): "Give but a little, and you will gain much; undo the primal sin by sharing your food. Just as Adam transmitted sin by eating wrongfully, so we wipe away the treacherous food when we remedy the need and hunger of our brothers and sisters" (Hom. 8.7). As Basil also regarded greed as the reason for the catastrophic famine and drought that struck Caesarea in 369 CE $(2,4)$, it was almsgiving that could restore the natural order and fruitfulness, imitate the earliest Christian community and receive the greatest return from God $(6,8)$. Ultimately for Basil, whereas greed makes one "unsociable", almsgiving makes one "sociable" for human flourishing $(7,5)$.

Augustine's teaching on almsgiving, in accordance with the broader tradition and shaped against a radical vision of total rejection of wealth as evil by his opponents (such as the Manichaeans and Pelagians), affirms redemptive almsgiving as the effectual means of repentance for the givers. In his controversy with Pelagius, Augustine democratized human nature in original sin and rejected Pelagian triumphalism in overcoming sin and living a life without sin by the baptized. Augustine then universalized the duty of almsgiving for the ordinary faithful (not just the rich) as not only works of justice but also the daily remedy for their daily sins "that was implied in the daily recitation of the Lord's Prayer". ${ }^{68}$ Coming back to the same issue addressed by Clement of Alexandria (Who is the Rich Man That Is Saved?) in that context, Augustine argues against heroic divestment and showy poverty, but enjoins the rich to regular almsgiving as part of their regular penance to remedy their pride and avarice. ${ }^{69}$ On the one hand, Augustine debunks the twin argument of the inherent goodness

66 This economic or transactional notion of almsgiving would be a standard theme for later church fathers. See, for example, Basil of Caesarea, Hom. 8.8;14.5; Gregory of Nazianzus, Or. 14.20, 22; Augustine, Serm. 107A.2; 42.2; 86.3.3; 239.5; En. in Ps. 38.7.12.

67 (Countryman 1980, p. 189)

68 (Brown 2012, p. 363; 2015, pp. 99-100). Matt 6.12: “Forgive us our sins" (Dimitte nobis debita nostra).

69 Cf. Brown (2012, p. 164). 
of poverty and the inherent evil of wealth and then turns to the apostle Paul's encouragement to the rich in 1 Tim. 6.17-19 (Ep. 157.23, 24, 26); on the other, he also affirms Jesus' command to the rich young man (Matt 19; Mark 10; Lk 18), by distinguishing the "commandments of the law and that of higher perfection" leading to life and perfection $(25,26)$. Harmonizing Paul's words of doing good works for the eschatological abode in 1 Tim 6.18-19 and the Lord's precept of keeping commandments in Matt. 19.19, Augustine puts forth the model for the righteous rich through almsgiving. Only then Augustine affirms the superiority of the righteous poor (i.e., monastics), who take up the Lord's counsel of voluntary poverty for perfection (33). In this way, Augustine supports a "two-tiered" system where he can approve both the ascetic/monastic poor on the road to perfection and "the weaker souls" (i.e., the righteous rich) who still put "their hope not in the uncertainty of riches, but in the living God" (33).

Finally, if avarice and pride are closely connected for the rich (also for the poor to an extent), humility in giving alms in critical in forgiveness of sins. Thus for Augustine, it is not the giving itself, but the disposition of giving that makes almsgiving salvific for the giver. ${ }^{70}$ Still, for Augustine it is the good works of the righteous rich and the ordinary faithful (i.e., the vast majority of Christians) that sustain the church and this world in its convalescence toward eschatological healing, not just the few elite perfectionists.

\subsection{The Institutionalized Philanthropy in the (Post-) Constantinian Era}

In the previous section, we have examined theological bases and practices of almsgiving as a fundamental expression of salvific philanthropy against destructive greed in the church fathers. In this last section, I will examine a unique institutional expression of Christian philanthropy in the (Post-) Constantinian era. In the Constantinian era, bishop assumed political and greater institutional and economic power and responsibilities not only for his Christian community but also for a larger Roman society. Constantine restored church properties along with religious freedom and granted the churches and bishops financial subsidy and clerical exemption from all compulsory public services and personal taxes. He exempted church lands and other properties from pious endowments and the taxation, endowed lands in many parts of the empire, and in sum provided the church with "the abundance of good things" (Eusebius, Hist eccl. 10.8.1). Furthermore, Constantine granted bishops the final judicial authority in arbitrating civil suits especially on behalf of the poor and his successors gave them unusual privileges of manumitting slaves in the church.

With imperial largesse (restricted to the Catholic Church, that is the Church Universal, not heretical church such as Arian church or schismatic church like Donatist church), Constantine made the church not only officially visible but also accountable to the public for the very public gifts it received. Up to this point, the church received offerings from the faithful, especially the middling group and the wealthy, because it primarily cared for the poor of its own, i.e., Christians. Now, the traditional Christian charity came to be regarded as a public service; and Christian identity was all the more linked to the church's care of the poor in Roman society, both Christians and non-Christians, as "the rich must assume the secular obligations and the poor must be supported by the wealth of the churches" (Cod. Theod. 16.2.6). With a Christian population reaching a majority in the mid-fourth century and Christianity becoming a major social force, the church would literally act as a mediator between the rich and the poor of the society and bishops emerged as "the lovers of the poor" and "the governors of the poor" in their public role. ${ }^{71}$

It is in this context that the most innovative kinds of Christian philanthropic institutions for the poor emerged throughout the Empire. ${ }^{72}$ By the end of the fourth century, various hostels (xenodocheia;

\footnotetext{
Cf. Allen and Morgan (2009, pp. 132-34).

71 Cf. Brown (2002, pp. 1, 32, 45); Rhee (2012, p. 181).

72 The subsequent paragraphs are modified from (Rhee 2017, pp. 128-31).
} 
xenōnes), poor houses (ptōchotropheia; ptōcheia), and lodges/hospices (katagōgia) devoted to collecting, housing, feeding, and caring for the poor and the sick sprang up in cities throughout the Eastern Empire, such as Caesarea, Antioch, Constantinople, Alexandria, and Jerusalem. These institutions were typically adjacent to churches and monasteries. For instance, Basil's famous katagōgia in Caesarea, built in the early 370s (c. $372 \mathrm{CE}$ ), was modeled after that of Eustathius, a homoiousian bishop of Sebasteia, who had designed his poor house (ptōchotropheion) to serve persons afflicted with diseases and disabilities. ${ }^{73}$ Basil's "New City" (Basileias as it was called by Gregory Nazianzen) housed strangers, the poor, the sick, and the elderly as well as lepers and the mutilated, many of whom needed medical treatments and care. ${ }^{74}$ It employed both physicians ("those who give medical care") and nursing staff in addition to his monastic staff. ${ }^{75}$ It also provided patients with the means to reintegrate into society by training them in crafts, skills and other occupations for their livelihood, presumably upon their recovery (Basil, Ep. 94). In Constantinople, Macedonius, a semi-Arian bishop, had already founded several poor houses (ptōcheia) that took in the sick and destitute in the mid-fourth century (Sozomen, HE 4.27). Shortly thereafter in the early 380s, the empress Placilla, the first wife of Theodosius I, conducted her rounds of xenones attached to the churches in the city, offering the patients meals (Theodorect, HE 5.19.2-3). John Chrysostom, upon his episcopal appointment in 398, not only financially supported the existing sick houses (nosokomeia) but established several more, placing them under the control of his trusted clergy, and hiring doctors (iatrous), cooks, and other staff for medical care of the sick (Palladius, Dial. 5). As a final example, in the mid-fifth century, the ascetic Theodosius established a nosokomeion near Jerusalem with three separate buildings staffed with physicians: one for monks, one for the "regular sick", and one for the poor, "who would be more permanent patients than the others" (Vita Theodosii 40). ${ }^{76}$

As institutions attached to churches or monasteries, these hospitals provided religious spaces with ceremonies, routines, and expectations intended to affirm and/or reaffirm the Christian faith among the patients-almost exclusively the destitute and strangers who needed nursing and "doctoring".77 If we infer from descriptions by the church fathers, the "admission rituals" for these institutions stressed the priority of spiritual well-being over bodily health. ${ }^{78}$ For example, cleansing the soul through confession of sins was to precede any efforts to care for the body, and rituals of prayer and vigils were part of the routine, especially during crises such as famines, epidemics, and wars. ${ }^{79}$ Patients, who were segregated by their gender whenever possible, were also expected to uphold basic Christian character, moral instructions, and the discipline of the institutions as seen in the Basileias (see Gregory of Nazianzus, Or. 43.63). ${ }^{80}$ Despite their general dependency and lack of control in that setting, some patients acted in recalcitrant ways, throwing their food, refusing to follow the physician's orders, and tearing the clothes of their caregivers. Morally suspect and unruly patients were to be exhorted and admonished by the superior, but if they persisted in the same conduct, condemnation and expulsion would follow, as would be expected for the monks in Basil's monastery. ${ }^{81}$

This fundamental religious expectation and the prioritizing of the patient's spiritual health was a natural corollary to the ideal of Christ as the Great Physician, primarily of the soul, but also of the body. ${ }^{82}$ The Cappadocian Fathers and John Chrysostom (following Origen) are among the early Christian leaders who show the greatest familiarity, knowledge, and positive attitudes toward Greek

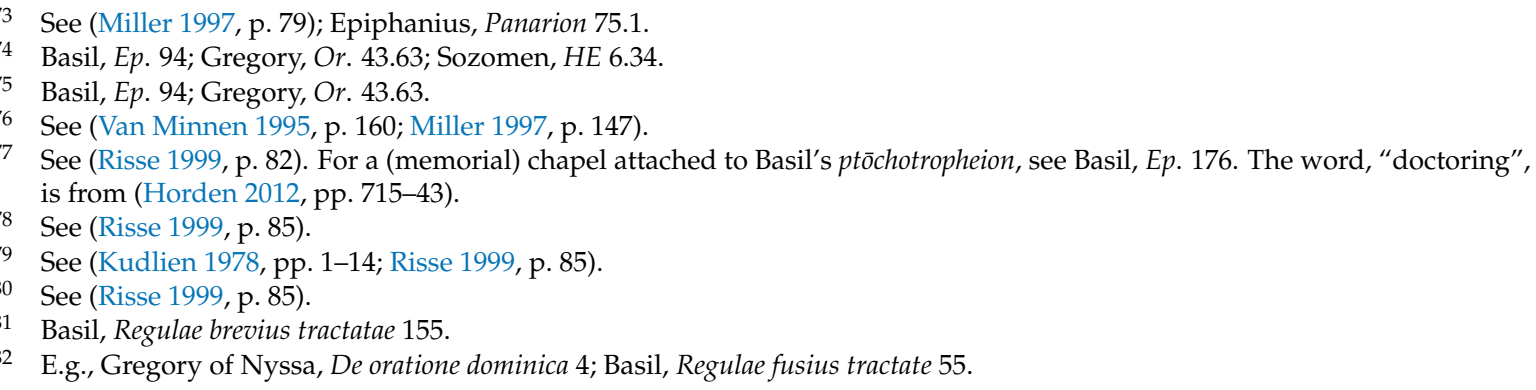


(Hippocratic/Galenic) medicine. For them, the medical art for somatic diseases is in harmony with Christian piety as "a model for the therapy of the soul" so long as both the patients and the doctors keep in mind the need to glorify God, eschew unwarranted human reliance, and uphold spiritual health as the highest priority. ${ }^{83}$ Basil therefore praised a Christian physician Eustathius for his philantrōpia in tending to the patients not just in their physical ills but also their spiritual ills (Ep. 189.1), and this was a sentiment echoed by the rest of the Cappadocian Fathers and John Chrysostom. Consequently, it was only natural from their perspectives that the patients understood or were instructed about the priority of the soul over the body for their holistic treatment even as they were given palliative care and (limited) medical attention in those institutions.

Along with religious expectations and routines, diet, rest, and nursing constituted the regular regimen offered in nosokomeia, ptōcheia, and xenodocheia. ${ }^{84}$ Patients were fed the standard Byzantine diet of "bread, wine, and dried or fresh cooked vegetables dressed with olive oil", as well as barley soup and honey boiled in water (Theodoret, HE 5.19.2-3). ${ }^{85}$ They received most of their nursing and care from non-medical personnel, including monastics and lay volunteers, some of whom might have had some basic medical training, and who were under the supervision of clergy, deacons, and deaconesses. Where physicians were available, those with internal ailments and external wounds would have received drugs, some counterirritation, and/or even surgical treatments. ${ }^{86}$ The most notable patients in the Basileias were lepers, ${ }^{87}$ who were housed and fed "indefinitely" with treatment of their wounds and bodily care, although they had no hope of recovery. ${ }^{88}$ Basil not only exhorted the healthy to treat them with dignity as "brother"' but also cared for them in person as an example to others (Gregory of Nazianzus, Or. 43.63). These new healing institutions largely emphasized solidarity with their patients (the lepers, the indigent, and migrants), as the ones who bear God's image and share a common humanity, as in the words of Jerome: "He whom we look down upon, whom we cannot bear to see, the very sight of whom causes us to vomit, is the same as we, formed with us from the selfsame clay, compacted of the same elements. Wherever he suffers we also can suffer" (Jerome, Ep . 77.6). These patients are almost certainly the same kind as the destitute (ptōchoi) and the leperous (also identified as ptōchoi) mentioned in Gregory Nazianzen's Oration 14 and Gregory Nyssa's On the Love of the Poor (although neither of them mentions the Basileias in their sermons). They are Christ in disguise and their physical (sick and bedridden) bodies in fact bear Christ's own incarnate body ${ }^{89}$ As fellow bearers of God's image, "our kindred", brothers, and the very person (prosōpon) of Christ, they not only deserve and are entitled to Christian care but also are holy and pious. Lepers, in particular, are compared with Lazarus, the "sacred beggar" in Luke's Gospel, and bear the "public infirmity" (koine astheneia; Gregory of Nazianzus, Or. 14.8) and the 'sacred disease' (hiera nosos), a designation ancient medical writers attribute to epilepsy ${ }^{90}$ (Or. 14.6; Gregory of Nyssa, Anim. Et res.). Due to their poverty and/or leprosy, then, the sick bodies of the poor, i.e., of the patients taken to the hospitals from the streets, are imbued with a certain sanctity by their patrons and bishops and require physical care from the "healthy". ${ }^{91}$ In this way, the newly established institutional Christian philanthropy (i.e., hospitals) would provide for the poor and the sick the most urgent and prominent place of refuge and hospitality until the modern times with further theological and spiritual significance.

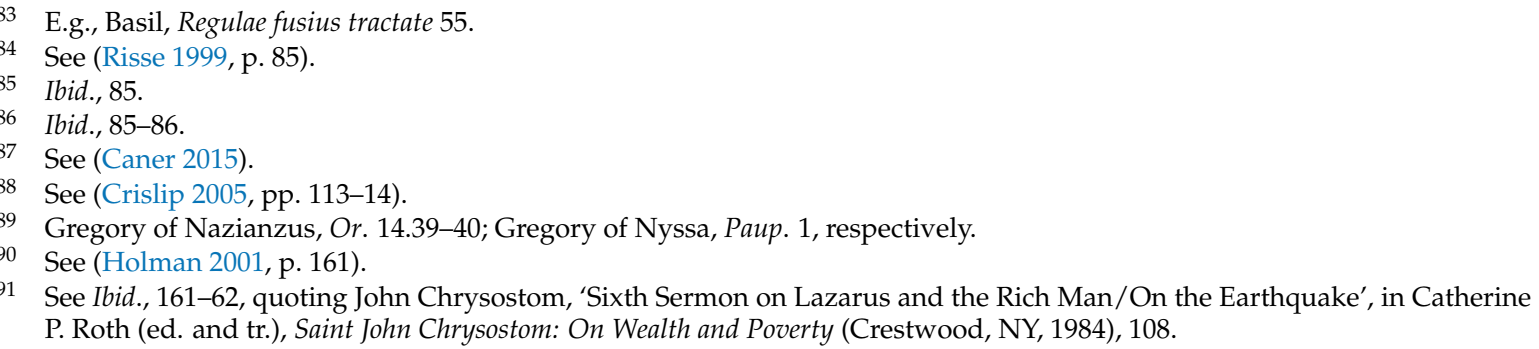




\section{Conclusions}

This article has examined the patristic understandings and practices of philanthropy and human flourishing with a broad stroke, presenting representative perspectives in shifting contexts rather than a focused or exhaustive study. I offer the following concluding thoughts and points:

First, patristic authors envisioned human flourishing in light of God's creation as they looked back to the prelapsarian paradigm of common ownership, sharing and use of God's material abundance and provision. Human need to delight in God includes our creaturely need to appreciate God's creation and abundance through material means, ${ }^{92}$ as God's shalom, wholeness, is all-encompassing-material as well as spiritual. In this sense, material things, when properly appreciated, serve as channels through which God manifests God's goodness and are intended to point us toward God, reflecting God's philanthrōpia, beauty, and glory.

Second, as the patristic theologians recognized the necessity and significance of material goods for human flourishing (in subordination of spiritual goods), liberal circulation of those goods was absolutely necessary for human flourishing. Hence, their call to almsgiving and establishment of philanthropies (e.g., hospitals/hospices/hostels) as both the works of charity and justice was never meant to be a mere rhetorical gesture but reflected their understanding of God's love and justice and human responsibility to respond to them in both individual and social contexts. This divine and human philanthropy then formed a critical identity marker for early Christian community formation and solidarity.

Third, in calling for redemptive almsgiving, the patristic authors looked toward the future, the new creation and the eschatological reality in which God's justice would reign and God's reward would be bountiful. This was an act of faith and hope in God's promise and restoration of the world in their present reality of socio-economic inequalities and oppression.

Fourth, their denunciation of greed and luxury points to their concern for distributive justice, which should constitute the faithful's journey of salvation. This would mean that at least theologically and ethically, meeting basic human needs (others' and our own) in terms of providing a real access to means of sustenance should be a fundamental ground and goal for economic and socio-political choices, activities and system(s). ${ }^{93}$ This principle also implies that the concern to meet others' needs takes priority over accumulation of one's surplus assets or display of his or her refined taste on luxury items.

Finally, theological anthropology does matter for appreciating early Christian philanthropy and their vision of human flourishing. To understand God's philanthropia and practice it with one another, early Christians had to understand who humanity was-sharing in the divine logos as the eikon of God, not just Christians but all members of humanity, particularly the poor, the lepers, the migrants, and the sick (i.e., the most vulnerable of the society), all equally bearing the incarnate body of Christ the Son. God loves this humanity and we do likewise. This key theological anthropology governed early Christians' practices of philanthropy then and can be welcomed and restored in our contemporary practices of Christian philanthropy now.

Funding: This publication was made possible in part through the support of the Theology of Joy and the Good Life Project, funded by a grant from the John Templeton Foundation.

Acknowledgments: The opinions expressed in this publication are my own and do not necessarily reflect the views of the John Templeton Foundation.

Conflicts of Interest: The authors declare no conflicts of interest.

92 Cf. Volf (1995, p. 188); (Schneider 2002, pp. 41-64).

93 Cf. Wolterstorff (1995, p. 151). 


\section{Primary Sources}

Augustine. Exposition on Psalm 38. 1956. In Sancti Aurelii Augustini Enarrationes in Psalmos I-L. Edited by E. Dekkers and J. Fraipont. Corpus Christianorum series Latina 38. Turnhout: Brepols.

Augustine. Letters 130 and 157. 1865. In Sancti Aurelii Augustini, Hipponensis episcopi, opera omnia, vol. 3 pt. 2. Edited by J.-P. Migne. Patrologia Latina 33. Paris: Imprimerie Catholique.

Augustine. On Christian Doctrine. 1962. In Sancti Aurelii Augustini De doctrina christiana; De vera religione. Edited by Josef Martin. Corpus Christianorum series Latina 32. Turnhout: Brepols, 1962.

Augustine. Sermons. 1861. In Sancti Aurelii Augustini, Hipponensis episcopi, opera omnia, vol. 5 pt. 1. Edited by J.-P. Migne. Patrologia Latina 38. Paris: Imprimerie Catholique.

Basil the Great. 2009. On Social Justice: St. Basil the Great. Translated by C. Paul Schroeder. Crestwood: St. Vladimir's Seminary Press.

Basil the Great. Homily 6. Homily 7. The Shorter Rules. 1977. In Sancti patris nostri Basilii, Cæsareæ Cappadociæ archiepiscopi, opera omnia quæ exstant, vol. 3. Edited by J.-P. Migne. Patrologia Graeca 31. Paris: Imprimerie Catholique, 1857. Reprint, Turnhout: Brepols.

Clement of Alexandria. Clementis Alexandrini Paedagogus. 2002. Edited by M. Marcovich. Supplements to Vigiliae Christianae 62. Leiden/Boston: E. J. Brill.

Clement of Alexandria. Exhortation to the Greeks/The Rich Man's Salvation. 1919. Translated by G. W. Butterworth. Loeb Classical Library. Cambridge: Harvard University Press.

Clement of Alexandria. Stromata. 1857. Patrologia Graeca 8-9. Edited by J.-P. Migne. Paris: Imprimerie Catholique.

Clement of Alexandria. Stromateis: Books 1-3. 1991. Translated by J. Ferguson. The Fathers of the Church 85. Washington: Catholic University of America Press.

Cyprian. De Lapsis and De Ecclesiae Catholicae Unitate. 1971. Text and Tr. M. Bevenot. Oxford: Clarendon Press.

Cyprian. Saint Cyprian: Treatises. 1958. Translated and Edited by R. J. Deferrari. The Fathers of the Church. New York: Fathers of the Church.

Cyprian. The Letters of St. Cyprian of Carthage. 4 Vols. 1984-1988. Translated and Annotated by G. W. Clarke. Ancient Christian Writers 43-47. New York \& Ramsey: Newman Press.

Gregory of Nazianzus. Oration 14: On the Love of the Poor. 1857. In Sancti patris nostri Gregorii Theologi, vulgo Nazienzeni, archiepiscopi constantinopolitani, opera quæ exstant omnia, vol. 1. Edited by J.-P. Migne. Patrologia Graeca 35. Paris: Imprimerie Catholique.

Gregory of Nyssa. On the Love of the Poor 1. 1964. In De pauperibus amandis orationes duo. Edited by Arie van Heck. Leiden: Brill.

John Chrysostom, 1984. Sixth Sermon on Lazarus and the Rich Man/On the Earthquake. In Saint John Chrysostom: On Wealth and Poverty. Edited and Translated by Catherine P. Roth. Crestwood, NY, pp. 97-124.

John Chrysostom. Homilies on the Acts of the Apostles. 1978. In Sancti patris nostri Joannis Chrysostomi, archiepiscopi constantinopolitani, opera omnia quæ exstant, vol. 9. Edited by J.-P. Migne. Patrologia Graeca 60. Paris: Imprimerie Catholique, 1858-1860. Reprint, Turnhout: Brepols.

John Chrysostom. Homilies on the First Letter to Timothy. 1968. In Sancti patris nostri Joannis Chrysostomi, archiepiscopi constantinopolitani, opera omnia quæ exstant. Edited by J.-P. Migne. Patrologia Graeca 62. Paris: Imprimerie Catholique, 1860. Reprint, Turnhout: Brepols.

John Chrysostom. Homilies on the Gospel of Matthew. 1978. In Sancti patris nostri Joannis Chrysostomi, archiepiscopi constantinopolitani, opera omnia quæ exstant, vol. 7 pts. 1-2. Edited by J.-P. Migne. Patrologia Graeca 57-58. Paris: Imprimerie Catholique, 1858-1860. Reprint, Turnhout: Brepols.

Lactantius. 2003. Divine Institutes. Translated and Intro. by A. Bowen and P. Garnsey. Liverpool: Liverpool University Press, 2003.

Pelagius, “On Riches”, Tr. B. R. Rees, The Letters of Pelagius and His Followers. 1991. Woodridge and Rochester: Boynton Press, pp. 171-211.

Sancti Cypriani Episcopi Opera. Pars II: Ad Donatom, De mortalitate, Ad Demetrianom, De opera et eleemosynis, De zelo et livore. 1976. Corpus Christianorum Series Latina. Turnholti: Typographi Brepols Editores Pontificii.

Tertulliani Opera. Pars I: Opera Catholica Adversus Marcionem. 1954. Corpus Christianorum Series Latina. Turnholti: Typographi Brepols Editores Pontificii. 
Theodoret of Cyrus. On Providence. 1864. In Theodoretou Episkopu Kyrou, Apanta. Theodoreti Cyrensis Episcopi opera omnia. Edited by J. P. Migne. Vol. 4, Paris: J.-P. Migne. Patrologiae Graeca, 83. Paris: Imprimerie Catholique, 1864.

Theodoret of Cyrus. Theodoret of Cyrus. On Divine Providence. 1988. Translated and Annotated by T. Halton. Ancient Christian Writers 49. New York, N.Y.: Newman Press.

Two Coptic Homilies Attributed to the Saint Peter of Alexandria: On Riches, On the Epiphany. 1993. Translated and Edited with Intro. B. Pearson and T. Vivian with D. B. Spanel. Roma: C.I.M.

\section{References}

Allen, Pauline, and Edward Morgan. 2009. Augustine on Poverty. In Preaching Poverty in Late Antiquity: Perceptions and Realities. Edited by Pauline Allen, Bronwen Neil and Wendy Mayer. Leipzig: Evangelische Verlagsanstalt, pp. 119-70.

Anderson, Gary A. 2007. Redeem Your sins by the Giving of Alms: Sin, Debt, and the 'Treasury of Merit' in Early Jewish and Christian Tradition. Letter \& Spirit 3: 39-69.

Anderson, Gary A. 2013. Charity: The Place of the Poor in the Biblical Tradition. New Haven and London: Yale University Press.

Brent, Allen. 2010. Cyprian and Roman Carthage. Cambridge and New York: Cambridge University Press.

Brown, Peter. 2002. Poverty and Leadership in the Later Roman Empire. Menahem Stern Jerusalem Lectures. Hanover: University Press of New England.

Brown, Peter. 2012. Through the Eye of a Needle: Wealth, the Fall of Rome, and the Making of Christianity in the West, 350-550 AD. Princeton and Oxford: Princeton University Press.

Brown, Peter. 2015. The Ransom of the Soul: Afterlife and Wealth in Early Western Christianity. Cambridge: Harvard University Press.

Caner, Daniel. 2015. Not a Hospital but a Leprosarium: Basil's Basliad Revisited. Paper presented at the Shifting Frontiers Conference XI, Iowa City, IA, USA, March 26-29.

Clarke, G. W. 1969. Some Observations on the Persecution of Decius. Antichthon 3: 68-73. [CrossRef]

Countryman, L. William. 1980. The Rich Christian in the Church of the Early Empire: Contradiction and Accommodations. New York: Edwin Mellen.

Crislip, Andrew T. 2005. From Monastery to Hospital: Christian Monasticism and the Transformation of Health Care in Late Antiquity. Ann Arbor: University of Michigan Press.

De Faye, Eugene. 1929. Origen and His Work. New York: Columbia University Press.

Downs, David. J. 2016. Alms: Charity, Reward, and Atonement in Early Christianity. Waco: Baylor University Press.

Dunn, Geoffrey D. 2004. The White Crown of Works: Cyprian's Early Pastoral Ministry of Almsgiving in Carthage. Church History 73: 715-40. [CrossRef]

Finn, Richard. 2006. Almsgiving in the Later Roman Empire: Christian Promise and Practice 313-450. Oxford: Oxford University Press.

Frend, W. H. C. 1986. The Rise of Christianity. London: Darton Longman \& Todd.

Garrison, Roman. 1993. Redemptive Almsgiving in Early Christianity. Sheffield: JSOT Press.

Gotsis, Georege N., and Gerasimos A. Merianos. 2007. Wealth and Poverty in Theodoret of Cyrrhus' on Providence. Journal of Eastern Christian Studies 59: 11-48. [CrossRef]

Groh, Dennis E. 1971. Tertullian's Polemic against Social Co-Optation. Church History 40: 1-14. [CrossRef]

Hicks, Douglas A. 2010. Money Enough: Everyday Practices for Living Faithfully in the Global Economy. San Francisco: Jossey-Bass.

Holman, Susan R. 2001. The Hungry Are Dying: Beggars and Bishops in Roman Cappadocia. Oxford Studies in Historical Theology. Oxford and New York: Oxford University Press.

Holman, Susan R. 2009. God Knows There's Need: Christian Responses to Poverty. Oxford and New York: Oxford University Press.

Horden, Peregrine. 2012. Poverty, Charity, and the Invention of the Hospital. In The Oxford Handbook of Late Antiquity. Edited by Scott F. Johnson. Oxford and New York: Oxford University Press, pp. 715-43. 
Hughson, Thomas. 2011. Social Justice in Lactantius's Divine Institutes: An Exploration. In Reading Patristic Texts on Social Ethics: Issues and Challenges for Twenty-First-Century Christian Social Thought. Edited by Leemans Johan, Brian J. Matz and Johan Verstraeten. Washington: The Catholic University of America Press, pp. 185-205.

Kudlien, Fridolf. 1978. Beichte und Heilung. Medizinhistorisches Journal 13: 1-14. [PubMed]

Maier, Harry O. 1994. Clement of Alexandria and the Care of the Self. Journal of the American Academy of Religion 62: 719-45. [CrossRef]

Matz, Brian. 2011. The Principle of Detachment from Private Property in Basil of Caesarea's Homily 6 and Its Context. In Reading Patristic Texts on Social Ethics: Issues and Challenges for Twenty-First-Century Christian Social Thought. Edited by Leemans Johan, Brian J. Matz and Johan Verstraeten. Washington: The Catholic University of America Press, pp. 161-84.

Michaels, J. Ramsey. 1998. Almsgiving and the Kingdom within: Tertullian on Luke 17:21. The Catholic Biblical Quarterly 60: 475-83.

Miller, Timothy. 1997. The Birth of the Hospital in the Byzantine Empire. Baltimore: Johns Hopkins University Press.

Raditsa, L. 1985. The Appearance of Women and Contact: Tertullian's De Habitu Feminarum. Athenaeum 63: 297-326.

Ramsey, Boniface. 1982. Almsgiving in the Latin Church: The Late Fourth and Early Fifth Centuries. Theological Studies 43: 226-59. [CrossRef]

Ramsey, Boniface. 1999. Wealth. In Augustine through the Ages: An Encyclopedia. Grand Rapids: Eerdmans, pp. 878-79.

Rhee, Helen. 2011. Wealth, Poverty, and Eschatology: Pre-Constantine Jewish and Christian Social Thoughts and the Hope for the World to Come. In Patristic Social Ethics: Issues and Challenges. Edited by J. Leemans, B. Matz and J. Verstraeten. Washington: Catholic University of America Press, pp. 64-84.

Rhee, Helen. 2012. Loving the Poor, Saving the Rich: Wealth, Poverty, and Early Christian Formation. Grand Rapids: Baker Academic.

Rhee, Helen. 2017. Portrayal of Patients in Early Christian Writings. Studia Patristica 81: 127-38.

Risse, Guenter B. 1999. Mending Bodies, Saving Souls: A History of Hospitals. New York: Oxford University Press.

Sage, Michael M. 1975. Cyprian. Patristic Monograph Series, No. 1. Cambridge: The Philadelphia Patristic Foundation, Ltd.

Schneider, John R. 2002. The Good of Affluence: Seeking God in a Culture of Wealth. Grand Rapids: Eerdmans.

Van Minnen, Peter. 1995. Medical Care in Late Antiquity. Clio Medica: Acta Academia Internationalis Historiae Medicinae 27: 153-69.

Volf, Miroslav. 1995. In the Cage of Vanities: Christian Faith and the Dynamics of Economic Progress. In Rethinking Materialism: Perspectives on the Spiritual Dimension of Economic Behavior. Edited by R. Wuthnow. Grand Rapids: Eerdmans, pp. 169-91.

Wolterstorff, Nicholas. 1995. Has the Cloak Become a Cage? Charity, Justice, and Economic Activity. In Rethinking Materialism: Perspectives on the Spiritual Dimension of Economic Behavior. Edited by R. Wuthnow. Grand Rapids: Eerdmans, pp. 145-68.

(C) 2018 by the author. Licensee MDPI, Basel, Switzerland. This article is an open access article distributed under the terms and conditions of the Creative Commons Attribution (CC BY) license (http:// creativecommons.org/licenses/by/4.0/). 